\title{
Strategic Mergers and Acquisitions in Higher Education: A Case Study from the UK
}

\author{
Margarita Georgieva* \\ Advanced Engineering Department, Blackpool and The Fylde College, Ashfield Road, Blackpool FY2 0HB \\ E-mail:mgeo@blackpool.ac.uk \\ Abdelrahman Abdelazim \\ Advanced Engineering Department, Blackpool and The Fylde College, Ashfield Road, Blackpool FY2 0HB \\ E-mail: aab@blackpool.ac.uk
}

\begin{abstract}
A recent trend for higher education in the UK sees increased collaboration and partnerships between technical colleges and universities. This represents a significant step in the redesign of the educational landscape that aims to synergise the industry advantages of colleges with the academic strengths of universities. The initial research fort this paper consists in investigations into technical college mergers with universities and university acquisitions of the period 2018-2020, along with an analysis of the advice and guidance circulated by the Association of Colleges (AoC) since April 2016. A case study has then been chosen to illustrate the main features of such merges across higher education. SWOT, PESTLE and Porter's Five Forces analyses of a merger case study are followed by stakeholder analysis of the Board and Trustees, the companies that are closely or remotely linked to the success of the trust and the links that exist between the various players in this emerging network of educational institutions and organisations. The paper examines published financial statements from Coventry University, analysing the economic and other effects of the mergers. This paper focuses on Better Futures Multi Academy Trust (BFMAT), a collective of sixth form colleges now part of Coventry University Group (CUG). The work examines the Trust institutions and the effects the mergers have had on strategic business development, analysing BFMAT colleges pre- and post- merger, utilising CATWOE and Balanced Scorecard analyses. Some of the benefits noted so far are the increase of the sphere of influence of CUG, a broader recruitment pool, with greater diversity and inclusivity potential, which leads to a better fit with Government policies, market trends and industry demand. Given current data made available by the institutions, the paper presents a range of recommendations for future development and concludes that overall performance is positive, and the alliance represents a good example of a valuable merge.
\end{abstract}

Keywords: strategic business development, education business

DOI: $10.7176 / \mathrm{EJBM} / 12-33-01$

Publication date: November $30^{\text {th }} 2020$

\section{Introduction}

Unlike other sectors, education focuses strategic government concerns. It is representative of key areas of human activity with far-reaching impacts and long-lasting effects on economic growth and prosperity. (Martynova \& Renneboog, 2008) Some difficulties the sector faces result from negative impacts inflicted by combinations of competitive market trends and imprudent business management, often arising from misunderstanding the sector and its intricacies. (Department for Business, Innovation and Skills, 2013) We see educational institutions located within miles of each other competing over dwindling numbers of potential students, focusing on undiversified, unappealing offers with little industry engagement. We see departments within the same organisation competing against one another in an unhealthy strive to grab students regardless of long-term interests or progression opportunities. Competition can be a healthy and beneficent practice, but in a context of considerable skills gap and labour market shortages, the next generation cannot reap profit of million-pound losses incurred across colleges marketing weak value-for-money qualifications equivalent to weak long-term investment.

Further education (FE) colleges are essential for meeting growing skills gaps across the UK and are vital in the delivery of technical, industry-oriented education. However, some struggle with inadequate educational provision, low quality qualifications and customer dissatisfaction, ultimately resulting in limited budgets and lower revenues, leading to declining prestige and increasing competition across the sector. In the past five years, over $17 \%$ cuts in funding for students over 18 staying in college have added to an already unprofitable context of small class sizes and rising needs for renewed technological base and infrastructure. (Jack, 2019) Cuts in funding since 2011 present significant deterrents to study for students from disadvantages backgrounds, further reducing college incomes. As a result, the number of college mergers has increased since 2016 as vocational and technical training sectors face years of declining Government funding and significant enrolment declines. (Association of Colleges, 2020)

The concern with quality provision, rather than short-term profit becomes a feature of a relatively new, rare form of merger based on a broad range of guidelines issued by the AoC. It takes the form of a conversion of sixth 
form colleges which are annexed and assimilated by a higher education institution or merge within various private education providers or charitable trusts. (Table 1) College-university partnerships are not a new phenomenon and "associate college" models can be excellent examples of institutions partnering along the lines of long-term mutually beneficial working relationships. However, this new form of merger is a step further towards a consolidation of teaching models and educational philosophies, supported by unified leadership teams and common governing boards. (Burke, 2018)

Further Education institutions mergers and acquisitions for the period 2019-2020 show a clear increase in multiple institutions joining larger Higher Education providers or colleges. Previously throughout 2015-2018, the impact of college mergers has been controversial with negligible impact on profit margin, but with certain potential for increased income due to rationalisation and several favourable developments in non-financial variables such as number of learners and success rate. (Popov \& Cattoretti, 2019) The particular case of sixth form colleges establishing trusts in partnership with universities has proven successful, particularly when it comes to diversifying services and generating profits from flexible new products developed quickly and just in time to answer market and community needs. This model will be the subject of the present study firstly on account of its rarity, and secondly on account of the exceptional record of economic success it appears to enjoy since one of its first occurrences in 2015. (Department for Education, 2015) The specific case examined further stands as a unique example in this context as it appears to have merged not as a result of financial difficulties, but rather for the sake of developing quality and offering growth and expansion opportunities to a range of local institutions.

Table 1 Review of College Mergers and Acquisitions (2019-2020)

\begin{tabular}{|c|c|c|c|}
\hline $\begin{array}{l}\text { Merged } \\
\text { Institution }\end{array}$ & Merging Colleges & Details & Year \\
\hline $\begin{array}{l}\text { Better Futures } \\
\text { Multi Academy } \\
\text { Trust (Coventry } \\
\text { University) }\end{array}$ & $\begin{array}{l}\text { King Edward VI College } \\
\text { Nuneaton, Bilborough } \\
\text { Sixth Form College, } \\
\text { Gateway College }\end{array}$ & $\begin{array}{l}\text { Sixth form college conversion to } \\
\text { academy status; Joined a trust formed } \\
\text { by Coventry University; Applied to } \\
\text { join and engaged in public consultation }\end{array}$ & $\begin{array}{l}1 \text { January } 2019 \\
1 \text { November } 2019 \\
1 \text { April } 2020\end{array}$ \\
\hline Activate Learning & $\begin{array}{l}\text { Activate } \\
\text { Learning ,Bracknell and } \\
\text { Wokingham College, } \\
\text { Guildford College }\end{array}$ & $\begin{array}{l}\text { College merger under the Education } \\
\text { and Skills Agency and its predecessor } \\
\text { organisations; Single dissolution }\end{array}$ & $\begin{array}{l}10 \text { January } 2019 \\
29 \text { March } 2019\end{array}$ \\
\hline $\begin{array}{l}\text { Stamford Park } \\
\text { Trust }\end{array}$ & $\begin{array}{l}\text { Ashton-under-Lyne Sixth } \\
\text { Form College }\end{array}$ & $\begin{array}{l}\text { Sixth form college conversion to } \\
\text { academy status; Joined a trust that the } \\
\text { College set up in Tameside local } \\
\text { authority }\end{array}$ & 1 February 2019 \\
\hline $\begin{array}{l}\text { South } \\
\text { College }\end{array}$ & $\begin{array}{l}\text { South Essex College of } \\
\text { Further and Higher } \\
\text { Education, } \\
\text { College of Arospects } \\
\text { Technology }\end{array}$ & $\begin{array}{l}\text { College merger under the Education } \\
\text { and Skills Agency and its predecessor } \\
\text { organisations; Single dissolution }\end{array}$ & 1 February 2019 \\
\hline $\begin{array}{l}\text { The West Herts } \\
\text { College Group }\end{array}$ & $\begin{array}{l}\text { West Herts College, } \\
\text { Barnfield College }\end{array}$ & $\begin{array}{l}\text { College merger under the Education } \\
\text { and Skills Agency and its predecessor } \\
\text { organisations; Single dissolution }\end{array}$ & 1 February 2019 \\
\hline $\begin{array}{l}\text { Orbital South } \\
\text { Colleges }\end{array}$ & $\begin{array}{l}\text { East Surrey College, } \\
\text { Reigate School of Art, John } \\
\text { Ruskin College }\end{array}$ & $\begin{array}{l}\text { College merger under the Education } \\
\text { and Skills Agency and its predecessor } \\
\text { organisations; Incorporated RSA; } \\
\text { Single dissolution }\end{array}$ & 1 February 2019 \\
\hline $\begin{array}{l}\text { London South } \\
\text { Bank University }\end{array}$ & Lambeth College & $\begin{array}{l}\text { Merged with LSBU after Lambeth } \\
\text { College Corporation was dissolved and } \\
\text { its assets transferred to South Bank } \\
\text { Colleges, which is a company limited } \\
\text { by guarantee, and wholly owned } \\
\text { subsidiary of the university. It is being } \\
\text { designated as an FE institution under } \\
\text { the FE and HE Act } 1992 \text { and remains } \\
\text { in the FE sector. }\end{array}$ & 1 February 2019 \\
\hline Croydon College & $\begin{array}{l}\text { Croydon College, } \\
\text { Coulsdon College }\end{array}$ & $\begin{array}{l}\text { College merger under the Education } \\
\text { and Skills Agency and its predecessor } \\
\text { organisations; Single dissolution }\end{array}$ & 12 February 2019 \\
\hline
\end{tabular}




\begin{tabular}{|c|c|c|c|}
\hline $\begin{array}{l}\text { Merged } \\
\text { Institution }\end{array}$ & Merging Colleges & Details & Year \\
\hline $\begin{array}{l}\text { Havant and South } \\
\text { Downs College }\end{array}$ & $\begin{array}{lll}\text { Havant } & \text { College, } & \text { South } \\
\text { Downs } & \text { College, } & \text { Alton } \\
\text { College } & & \\
\end{array}$ & $\begin{array}{l}\text { College merger under the Education } \\
\text { and Skills Agency and its predecessor } \\
\text { organisations; Single dissolution }\end{array}$ & 1 March 2019 \\
\hline $\begin{array}{l}\text { Sunderland } \\
\text { College Group }\end{array}$ & $\begin{array}{l}\text { Sunderland College } \\
\text { Northumberland College }\end{array}$ & $\begin{array}{l}\text { Part of Education Partnership North } \\
\text { East } \\
\text { College merger under the Education } \\
\text { and Skills Agency and its predecessor } \\
\text { organisations; Single dissolution }\end{array}$ & 22 March 2019 \\
\hline $\begin{array}{l}\text { Worcestershire } \\
\text { Learning Trust }\end{array}$ & $\begin{array}{l}\text { Worcester Sixth Form } \\
\text { College }\end{array}$ & $\begin{array}{l}\text { Sixth form college conversion to } \\
\text { academy status; Formed a new multi } \\
\text { academy trust in Worcestershire }\end{array}$ & 1 April 2019 \\
\hline $\begin{array}{l}\text { Chichester } \\
\text { College Group }\end{array}$ & $\begin{array}{l}\text { Chichester College Group, } \\
\text { Worthing College }\end{array}$ & $\begin{array}{l}\text { College merger under the Education } \\
\text { and Skills Agency and its predecessor } \\
\text { organisations; Single dissolution }\end{array}$ & 1 April 2019 \\
\hline New City College & $\begin{array}{l}\text { New City College, } \\
\text { Havering } \text { College of } \\
\text { Further Education and } \\
\text { Higher } \\
\text { Havering } \\
\text { College }\end{array}$ & $\begin{array}{l}\text { College merger under the Education } \\
\text { and Skills Agency and its predecessor } \\
\text { organisations; Single dissolution x } 2\end{array}$ & 1 August 2019 \\
\hline $\begin{array}{l}\text { Esher Sixth Form } \\
\text { College Academy } \\
\text { Trust }\end{array}$ & Esher College & $\begin{array}{l}\text { Sixth form college conversion to } \\
\text { academy status; Formed a trust in } \\
\text { Surrey }\end{array}$ & $\begin{array}{ll}1 & \text { September } \\
2019 & \end{array}$ \\
\hline $\begin{array}{l}\text { City College } \\
\text { Norwitch, Suffolk } \\
\text { New College }\end{array}$ & $\begin{array}{l}\text { Easton and Otley College, } \\
\text { City College Norwich } \\
\text { (+Easton Campus), Suffolk } \\
\text { New College (+Otley } \\
\text { Campus renamed to } \\
\text { Suffolk Rural) }\end{array}$ & $\begin{array}{l}\text { EOC demerged and remerged in } 2 \\
\text { separate colleges.; College merger } \\
\text { under the Education and Skills Agency } \\
\text { and its predecessor organisations; } \\
\text { Single dissolution }\end{array}$ & 1 January 2020 \\
\hline SMB Group & $\begin{array}{l}\text { Brooksby Melton College, } \\
\text { Stephenson College }\end{array}$ & $\begin{array}{l}\text { College merger under the Education } \\
\text { and Skills Agency and its predecessor } \\
\text { organisations; Single dissolution }\end{array}$ & 31 January 2020 \\
\hline $\begin{array}{l}\text { Morley College } \\
\text { London }\end{array}$ & $\begin{array}{l}\text { Morley College, } \\
\text { Kensington and Chelsea } \\
\text { College }\end{array}$ & $\begin{array}{l}\text { College merger under the Education } \\
\text { and Skills Agency and its predecessor } \\
\text { organisations; Single dissolution }\end{array}$ & 3 February 2020 \\
\hline TEC Partnership & $\begin{array}{l}\text { Grimsby Institute, East } \\
\text { Riding College }\end{array}$ & $\begin{array}{l}\text { Formerly known as the Grimsby } \\
\text { Institute Group, planned merger for } \\
\text { August } 2020 \text {. }\end{array}$ & 1 August 2020 \\
\hline $\begin{array}{l}\text { Inspire Education } \\
\text { Group }\end{array}$ & $\begin{array}{lr}\text { Peterborough } & \text { Regional } \\
\text { College, New } & \text { College } \\
\text { Stamford } & \end{array}$ & $\begin{array}{l}\text { College merger under the Education } \\
\text { and Skills Agency and its predecessor } \\
\text { organisations; Single dissolution }\end{array}$ & 1 August 2020 \\
\hline $\begin{array}{l}\text { Trafford College } \\
\text { Group }\end{array}$ & $\begin{array}{l}\text { Trafford College } \\
\text { Cheadle and } \\
\text { College }\end{array}$ & $\begin{array}{l}\text { College merger under the Education } \\
\text { and Skills Agency and its predecessor } \\
\text { organisations; Single dissolution }\end{array}$ & $\mathrm{TBC}$ \\
\hline
\end{tabular}

\subsection{Overview of Existing FE Merger Guidelines and Trends}

Education is a heavily regulated business with several restrictions due to the nature of its services. In line with this, a range of guidelines and recommendations are issued for merging colleges by the Association of Colleges (AoC) and the Education and Skills Funding Agency (ESFA). To-date, most reliable sources with guidelines on mergers in education have been released between 2003 and 2016. Several issues arise from this as the lessons learned and the case studies they present are situated in an already outdated framework. (Department of Business, Innovation and Skills, 2015) The Guide on New Structures from the AoC and the only currently available comprehensive document for governors and senior leaders dates to 2016. Hence, the challenges of the fast-paced, technologicallycharged and risk-laden present have not been adequately reflected in these analyses. All institutions planning future mergers should have a measure of risk and opportunity, as well as sound planning that includes technological development and the rapidly changing demands of employers in what is a highly volatile international context of 
major politico-economic upheavals such as Brexit, social unrest and far-reaching instability caused by global force majeure such as pandemics, ecological and economic crises.

Overall, the currently available general guidelines and advice are derived from reports and analyses of various strategies to strengthen financially weakened colleges and to delineate potential action plans for delivering new college mergers as successful commercial ventures. Further aspects to consider for college mergers according to the AoC are broadly grouped into human resource, legal, and operations and process issues with various documentation and legal processes remaining on the front line. The core ideas behind the advice on merger processes for FE seem based on reorganisations of collaborative work, ideas about enhancing the support to students and a range of similar education-specific concerns with, systematically, a preoccupation with rating rather than an outright concern about financial strength. Business planning and profitability seem secondary, even though there is evidence of extensive advice on costs, including pension schemes and staffing issues.

The effects of a merger for colleges permeate all structures and the interests of all stakeholders, but in essence, the focal point is maintaining confidence in a uniquely wide palette of financially essential stakeholders including students, employers, other business partners and service providers, parents and local communities as well as councils, MPs, government and funding agencies. (Association of Colleges, 2016) The financial aspects are, in most cases, at the very origin of the decision to merge. In all known cases to-date, it is important to remember that colleges are also exempt charities and therefore all mergers are supposed to take this into consideration, ensuring that a newly formed entity will continue to benefit its stakeholders. Therefore, market as well as financial analysis of all merging institutions is a vital step to take before a merger is undertaken.

The timeline for mergers over 2008-2020 shows peaks and troughs with a considerable number of institutions merging after the 2008 global economic crisis. Between 2019 and 2020, over 20 college mergers across the UK have been recorded by the Association of Colleges (AoC). A newly rising trend is expected for late 2020 and 2021 as the UK moves into a post-Brexit environment. The need for significant restructuring has been delineated by the Department for Education in a sector report, outlining some of the most notable recommendations and lessons learned from merger implementation up to 2019. (Department for Education, 2019)

Figure 1 Distribution of College Mergers and Conversions

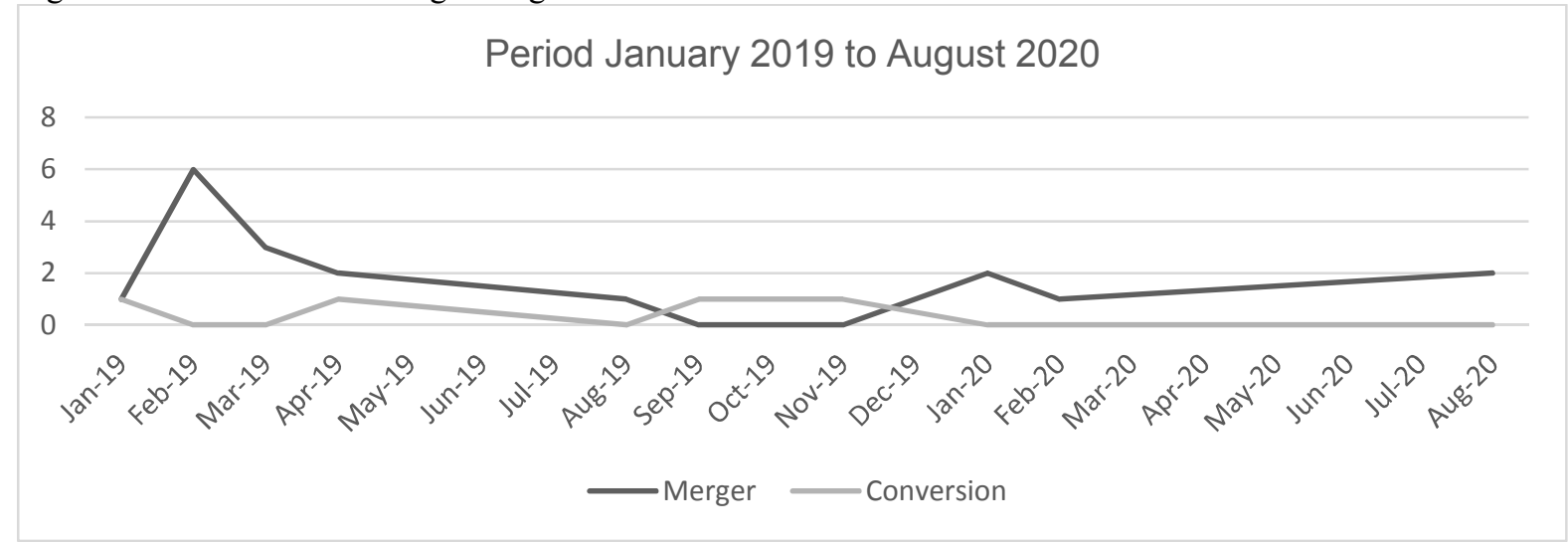

As evidenced in Table 1 and Figure 1, the trend for mergers and conversions peaked at the beginning of 2019 and has seen a stable increase throughout 2020. It appears that most mergers are the direct result of declining business performance, poor financial results and, overall, a struggle to remain competitive on the market. In addition, this is a complex process much to the same degree to as in all business sectors and the critical success factors are likewise measured by continued business performance KPIs. (Gomes, et al., 2013)

It appears that most mergers entail one or several colleges undergoing a dissolution with all assets, property and liabilities becoming part of another institution or a newly formed one. (Johnson, 2017) The AoC defines several types of college mergers, including single, double and triple dissolutions, transfers and acquisitions. While this seems to be a popular trend in FE, the period between 2018 and 2020, has seen a few failed mergers, institutions demerging and being taken over by various boards set up to manage Ofsted monitoring visits. More than 30 separate analyses of mergers revealed that the focus on quantity prevailed over the focus on quality, resulting in "inadequate" ratings. (Burke, 2018) College mergers with an HE provider are referred to as "transfers" (Association of Colleges, 2016) and are a recent and growing phenomenon.

The three colleges seem to have been in financial difficulties relative to their sizes. It is also evident that CUG and the associated managing trust of the merges had different agenda that focuses on quality and students' progression. The soft approach to managing the merge included maintaining college structures and operations. (Better Futures Multi-Academy Trust, 2019) As not-for-profit organisations impact on the public is still be seen but earlier signs reveal positive results in terms of quality and finance. The colleges' finances reveal constant income as expected from a local college whilst the constant loss indicates mismanagement and vital need for a 
rescue deal. On the other hand, CUG constant growth in an increasingly competitive global market indicates good progression coupled with strong visionary management. The university positive result is credited to merges, establishing new markets and diversifying student recruitment.

Early financial indicators for BFMAT reveal that unlike most M\&A activities, the CUG partnership has shown some success to deliver value for all parties. (Faulkner, et al., 2012) The merger comes with a good strategic fit while the organisational fit remains a challenge for a time. Currently, there is no indication of any short-term plans to fully integrate the acquired colleges into the university structure. (Johnson, et al., 2017) Negotiation steps previously involved a lengthy and detailed public consultation with all stakeholders. Although the integration documents are not publicly available yet, current practice does not reflect a short-term full integration plan with budgets kept strictly separate.

\section{Case Study: Better Futures Multi-Academy Trust (BFMAT)}

Better Futures Multi-Academy Trust (BFMAT) is constituted of King Edward VI College Nuneaton, a sixth form college that underwent conversion, attaining academy status in January 2019. This was followed by the application of Bilborough Sixth Form College to join the trust as of November 2019. A third college has applied and is engaged in public consultation with tentative date in April 2020. While most college mergers occur for financial and economic difficulties and appear a last-option scenario, attempting to save struggling institutions, BFMAT presents unique format comparatively to other merging colleges. It stems from an initiative to pursue economic and business growth through partnership.

Figure 2 Key Stakeholder Links to Strategic Management Operatives for BFMAT

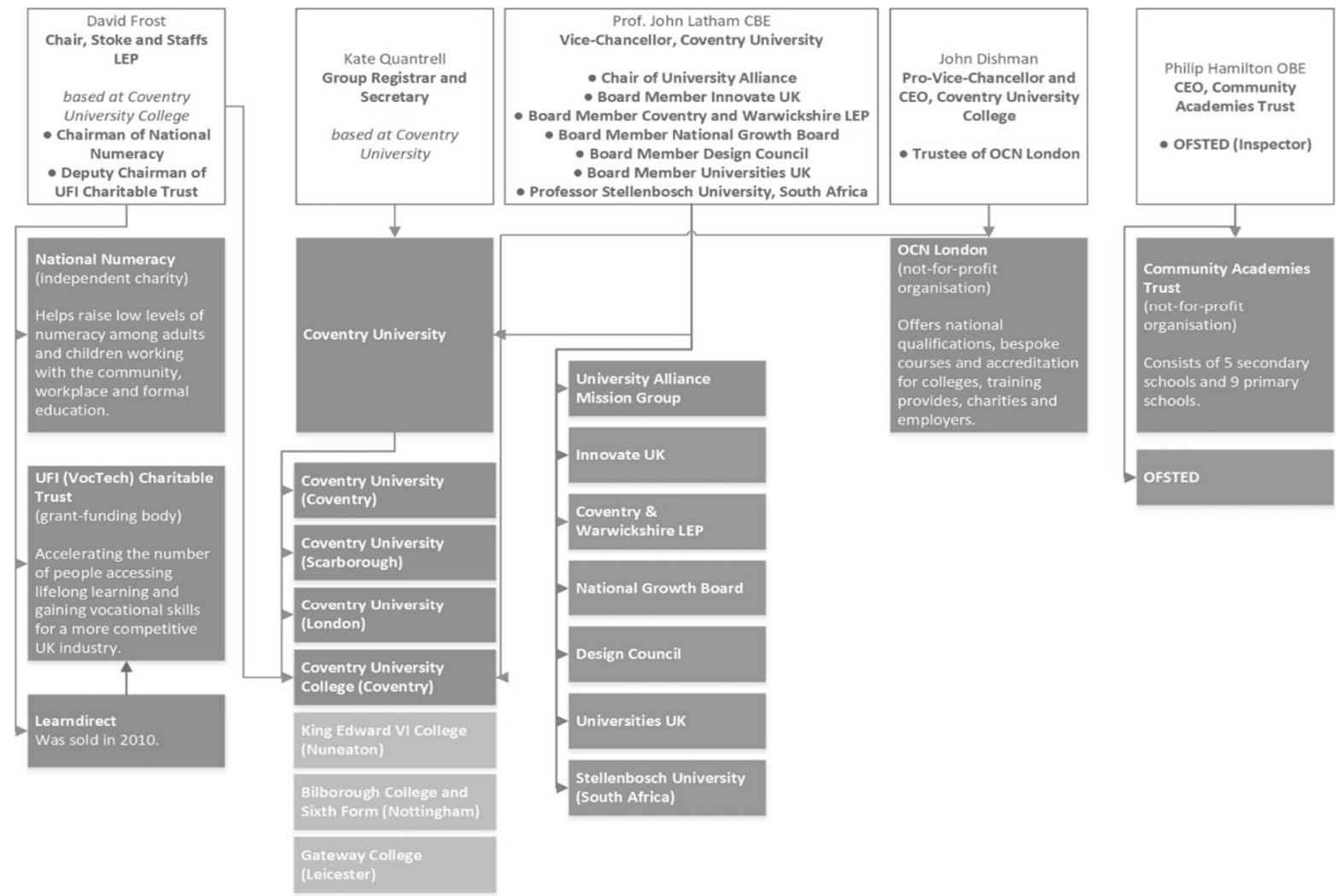

This is a unique case that represents an M\&A and strategic alliance to drive growth and achieve stability, particularly for the colleges involved. In comparison to for-profit organisations, the trust reflects government-led alliances and merges to save intangible cost and rationalise provision, enhancing quality of student experience whilst satisfying all stakeholders. It is inherently different to other organic developments carried out by Coventry University Group (CUG) that involve new department establishment and facility investments. (Johnson, et al., 2017) From an ideological and strategic perspective the format and scope of BFMAT concentrate on a collective strengthening of the provision of all colleges that comprise it with a collective objective to bring core values to life. The focused approach to nurturing common values is derived from the needs of its two main stakeholders CUG as its end client and students from a continually broadening geographical range as its main resource.

BFMAT is part of CUG's business growth strategy, seeking to broaden its services spectrum, specifically focusing on education and innovation in a top-down approach where higher education becomes an accelerator of potential. The focus are small satellite FE institutions. Their addition to the wider CUG family contributes to a 
widening sphere of influence in line with the widening participation concept for HE institutions. This expansion appears to happen regionally as well as nationally in the long-run, contributing to a significant diversification of services and income.

\subsection{Concept Uniqueness and Education Business Strategy}

The concept is unique in that its focus are sixth form colleges, identified for the purpose of gaining mutual benefit from structural relationships and collaborative initiatives. At its core lies a recruitment strategy with a systems approach to ultimately bringing students from diverse backgrounds and age groups to higher education whether through traditional or an e-learning and online delivery approach. When considering the four factors (Johnson, et al., 2017) for the impact of the choice for merger over an alliance, a significant variation is noted among the involved partners:

1. Urgency: For FE partners, urgency is evidenced by their financial standing and overall quality KPIs. CUG perspective reflects lower urgency as the merge widens its recruitment landscape.

2. Uncertainty: Fast-paced changes in education require different approaches to creating long-term stability. Strong collaborative networks, progression routes for local youth and new apprenticeship standards seems to be a winning strategy.

3. Capabilities (type and modularity): The mixed FE/HE capabilities, if managed appropriately, can lead to positive results as seen in similar partnerships, e.g. WMG Academy Trust (competitor).

From an economic and business perspective, BFMAT board members are like commercial company shareholders without receiving dividends. They own the trust, ensuring it operates like a charity. Stakeholder analysis of five board members in managerial leadership positions indicates a rich network of private companies, trusts, universities and colleges, as well as various strategic bodies including Ofsted, the Design Council, Universities UK and Innovate UK. Broader spheres of action are delineated across three types of institutions:

1. charitable organisations working in vocational education, skills training and lifelong learning, attracting students from significantly diverse backgrounds

2. universities, colleges, secondary and primary schools, demonstrating a unique vision of creating and maintaining strong links across all educational levels in order to guarantee progression opportunities

3. national bodies involved in policy-making and funding, including Innovate UK, LEPs, whose key contribution to BFMAT are financial, ideological and strategic, maintaining a wider awareness of the educational scene, industry developments and resulting changes in the job market, ensuring stable income as well as positive destinations for graduates.

Stakeholder analysis of BFMAT's managerial leadership team reveals a robust, well-connected, wellestablished team with clear and unified vision to create opportunity. Ofsted links are particularly precious as they have resulted in better understanding of requirements and, consequently, higher Ofsted rating of BFMAT institutions. The links to LEP networks ensure excellent industry need knowledge and power to influence the direction of economic growth in the regions that constitute spheres of CUG and BFMAT influence. Looking at the trust's competitive position, stakeholder analysis reveals considerable supplier power for BFMAT, decreasing the threat of market entry for potential rivals in the spheres of influence around Coventry. 


\subsection{Post-Merger SWOT Trends}

Figure 3: SWOT Analysis for BFMAT

\section{Strengths}

- Stronger provision with an increased quality of service.

- Better awareness of teaching content directions to answer the need of partner HE provider and its industry partners.

- Richer educational partnership network that favours collaborations.

- Clear progression opportunities for students.

- Better reputation locally and increased opportunities for staff.

\section{Weaknesses}

- Charity status will rely heavily on the not-for-profit format which will require strong financial accountability and may limit for-profit endeavours.

- Currently limited by delivery options (A-levels) with little diversity of product (no other qualifications offered).

- A widening network may result in loss of communication across partners and information channels may face bottlenecks.

\section{Threats}

- The COVID-19 pandemic is changing the way students interact with education and what they perceive as important in terms of skill training.

- Brexit will impact EU funding schemes and there will be changes relating to the right of EU nationals' access to publicly funded education as well as some teacher and staff recruitment issues in certain specialty areas.

- Buy-in and staff culture: there may be a need to unify mission and vision and to popularise the new drive to quality and continuous improvement than may not be fully embraced.

\section{Opportunities}

- Increased e-learning and online delivery opportunities that originate as risk mitigation strategies but can develop into long-term business opportunities.

- New re-skilling opportunities for a diverse out-of-work population.

- Developing the Trust with new members and potential international expansion or recruitment opportunities that are driven by the HE partner.

SWOT analysis focusing on the various aspects of BFMAT after the merger reveals that some of the aspects considered would also have been present in a SWOT analysis of a standalone college model, especially in terms of weaknesses. Here, the financial standing of the colleges is also linked to their offer and their position in the educational system. However, the merger may significantly improve the capacity of the colleges to affront and mitigate risks related to global threats and will combine individual strengths into a new collective. In addition, there is a clear link between existing threats and future opportunities. Given the broader mission and vision of the merged institution, current threats are clearly at the origin of a transformation strategy that will focus on the resulting opportunities.

The increased online delivery and vocational training through various e-learning platforms comes as a clear answer to the off-site teaching model currently encouraged by the Government. Additional expansion and recruitment opportunities driven by CUG will alleviate the pressure of Brexit as projected by the AoC. (Association of Colleges, 2020) The COVID-19 epidemic will present a significant threat in terms of economic and social effects on the population. There has been a projected rise in unemployment as companies across the services sectors close. However, herein lies a significant opportunity for the merger whose philosophy advocates education for populations of all ages. There may be opportunities of re-skilling workers for booming industries, including manufacturing, pharma, healthcare and connected sectors, including engineering. These are in turn affected by a variety of factors which are further discussed in the PESTLE analysis.

\section{Pre- and Post- Merger Status}

BFMAT institutions are diverse, reinforcing their market position. King Edward VI has a long history as flexible education provider, having survived numerous educational reforms. Bilborough and Gateway provide a contemporary, relaxed atmosphere.

BFMAT seems to fit under two categories as defined by Bower. (Bower, 2001) It is a clear geographic rollup M\&A, combined with a product and market extension. It is a geographical expansion and extension of a product line as seen in Figure 2 above. Undoubtedly, CUG will assist BFMAT colleges with access to capital, modern technology and will solve problems of local management, providing centralised leadership. The university is following commonly agreed M\&A guidelines such as holding on to key employees and customers rather than 
realising quick efficiencies for profit. By integrating them within a separate cell as part of its own structures, CUG will invest time in understanding how the colleges operate before undertaking further transformations and engaging in significant change management. (Bower, 2001)

Figure 4 Coventry University Sphere of Influence (pre- and post-merger)

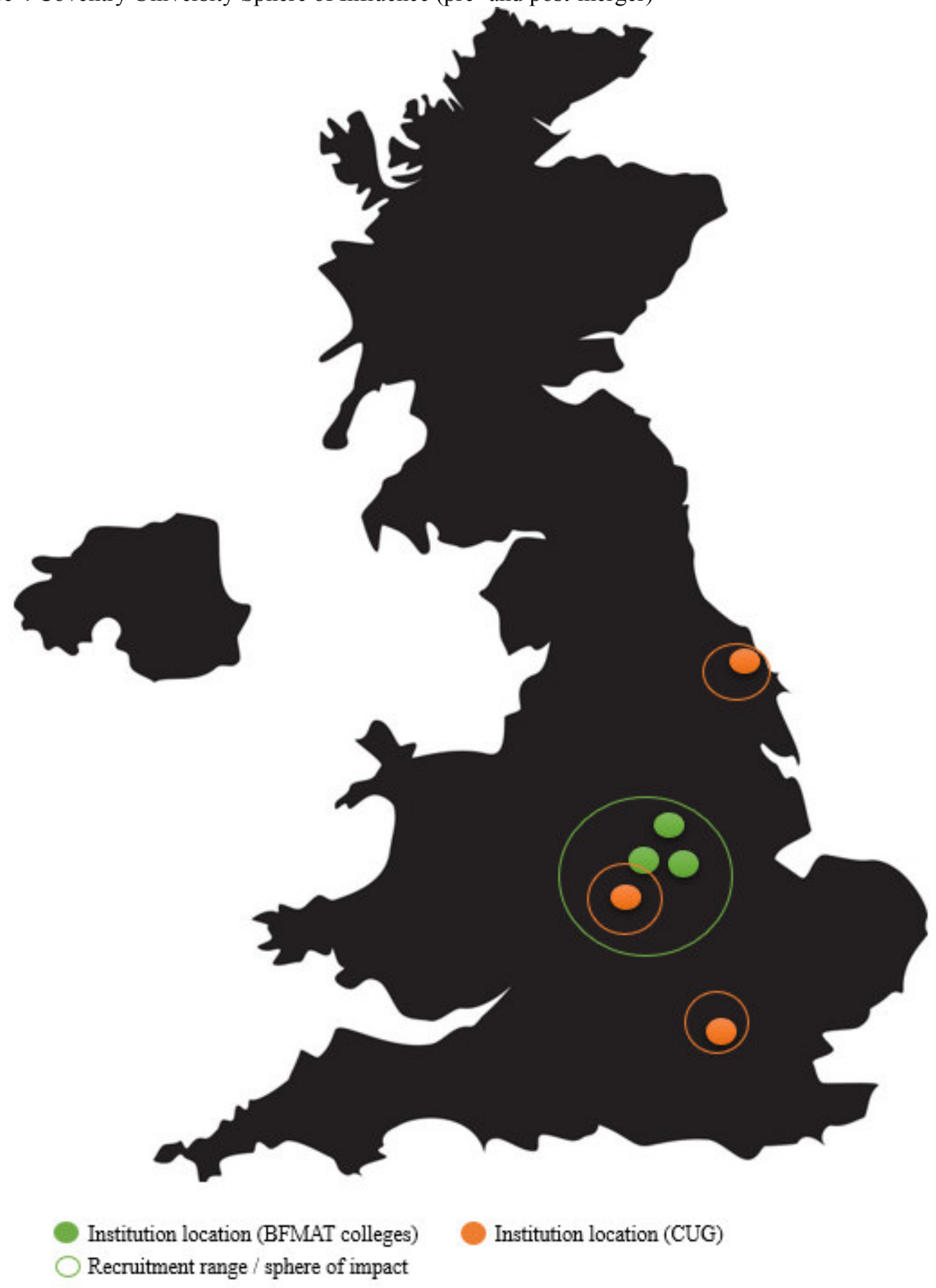

\subsection{Pre-Merger}

Analysis of transformation aspects for BFMAT as part of CATWOE analysis (Table 1) reveals that in a context of significant change, trying to ride with the change may be a better strategy overall. 
Table 1 CATWOE Analysis

\begin{tabular}{|c|c|}
\hline Customers & $\begin{array}{l}\text { Who are the main customers and those affected by the merger? } \\
\text { - Customers for the various colleges are very differently profiled with King Edward } \\
\text { VI College Nuneaton accepting more traditionalistic cohorts of students, looking } \\
\text { for solid grammar-school theoretical grounds at A-level combined with more } \\
\text { flexibility and a touch of contemporary freedom. } \\
\text { - Bilborough Sixth Form College and Gateway College are looking at improving } \\
\text { their quality of delivery but are also focused on considerable diversity in their } \\
\text { student body, having an increasing online offer as well as adult learners. } \\
\text { - In terms of students and personnel, the three colleges are very local and focused } \\
\text { on the environing areas but are also relatively large with 1500+ students each with } \\
\text { corresponding teaching, services and administration support. } \\
\text { How does the merger affect these customers? } \\
\text { - It has affected students favourably as it creates opportunities for progression. } \\
\text { - It has obviously affected staff at delivery level and this in a positive direction as } \\
\text { all colleges appear to be actively recruiting for various teaching ad administration } \\
\text { positions. }\end{array}$ \\
\hline Actors & $\begin{array}{l}\text { Who are the main stakeholders in the merger? } \\
\text { - In terms of an extended stakeholder analysis, the immediate actors are } \\
\text { administration and delivery-level personnel who will be delivering on operational } \\
\text { and policy changes. However, the wider participation of actors from CUG does } \\
\text { impact the experience of the customers, broadening their perspectives and options, } \\
\text { and exposing them to opportunities } \\
\text { What is the stakeholder involvement and participation in the merger and how they are } \\
\text { impacted? } \\
\text { The operational success is guaranteed by active participation in the merger. In is } \\
\text { crucial to obtain stakeholder buy-in and to lead an informative and reassuring } \\
\text { communication campaign in order to educate stakeholders about the merger } \\
\text { process and its various phases as well as the future mission and vision of the new } \\
\text { formation. }\end{array}$ \\
\hline $\begin{array}{l}\text { Transformation } \\
\text { Process }\end{array}$ & $\begin{array}{l}\text { What processes or systems are affected by the merger? } \\
\text { - Ofsted grades have improved as both Bilborough and Gateway gained "good" } \\
\text { standing after they initiated a close partnership within BFMAT. This means that } \\
\text { core policies and processes, including teaching, learning, assessing and care for } \\
\text { students have gained in quality. The transformation process permeates } \\
\text { institutional structures and obviously leads to creating a culture of continuous } \\
\text { improvement. } \\
\text { The transformation process will counteract any potential threats to the business of } \\
\text { the partners as reflected by the SWOT analysis. (Figure 3) }\end{array}$ \\
\hline World View & $\begin{array}{l}\text { How does the merger impact institutional mission and vision? } \\
\text { - The bigger picture ultimately presents a vision of growth and expansion as well as } \\
\text { a creation of a diverse educational community focused on small local hubs, } \\
\text { belonging to a larger whole that remains collaborative and open. This strategy } \\
\text { scores points in diversity as well as widening participation and inclusivity agendas } \\
\text { and may potentially affect funding opportunities. }\end{array}$ \\
\hline Owners & $\begin{array}{l}\text { Who directs the transformation process and the vision post-merger? } \\
\text { - CUG owns the merger process which is strategically managed by BFMAT Board } \\
\text { of Trustees. The wide professional network of its members presents numerous } \\
\text { opportunities but also contributes to a uniquely positioned strategy. }\end{array}$ \\
\hline
\end{tabular}




\begin{tabular}{|l|c|}
\hline Environmental & $\begin{array}{c}\text { What are the conditions and rules under which the business operates? } \\
\text { Constraints }\end{array}$ \\
The constitution of the new merger entails co-decision on key processes which \\
include admission procedures and criteria for all institutions as well as a range of \\
systematised, unified and consistent internal processes. In the short run, this will \\
necessitate training of staff and in the long-run it will contribute to a more \\
sustainable management of resources. \\
What are the constraints and limitations that will impact the solution and its success? \\
A perceived lack of independence and academic freedom may be some of the \\
initial constraints short term. However, long term, the transformation process will \\
integrate these concerns into a structured institutional framework that ensures \\
continuity from college to university. \\
In terms of physical resources, the institutions have not has additional constraints \\
and appear to have kept their estates and retain the management of their facilities \\
and assets albeit under a wider management forum. \\
Gateway College merger process is expected to be set back by the COVID-19 \\
epidemic.
\end{tabular}

\subsection{Post-Merger}

King Edward VI and Bilborough ranked good providers with Ofsted, achieving the rating post-merger. Students are earning top grades and progress to HE in their majority, $98 \%-99 \%$, ensuring continuous influx of students into CUG. Stakeholder management rather than college structures is BFMAT priority with a strategy to involve communities in continuous, lifelong education through vocational skills and e-learning, providing numerous FEHE passageways.

The post-integration process is challenging but is implemented softly. In terms of organisational fit, there are fundamental differences between $\mathrm{HE}$ and FE institutions. While university lecturers have higher level qualifications and, in most cases, they enjoy reduced teaching commitments compensated by research output expectations. However, there is a clear trend among universities to try and implement college-like teaching and learning philosophies by hiring college calibre technicians and lab assistants with industry backgrounds. The complementarity between the two is evident, particularly when considering the vocational know-how of FE college staff and their high involvement in industry through well-established apprenticeship schemes. (Johnson, et al., 2017)

\subsection{Balanced Scorecard (BSC) Analysis}

Analysis of BFMAT's strategy in the light of BSC reveals quality-focused tactics. BFMAT trustee stakeholder analysis reveals a rich network of contacts that permeates the educational landscape on many levels, including professional training, certification, and quality. Their professional networks and partnerships have contributed to the development of very clear marketing strategy, helping customers see BFMAT in the light of continuous betterment and personal success.

Unlike for-profit M\&A, motives for this merge are clearly customer-facing and announced reasons reflect real intent. The nature of customers and government involvement create complex layers of public interest and therefore a more elaborate customer base which may be difficult to serve. Financially speaking, taxpayer investment requires a sensitive approach, accountability and clarity in the steps taken to ensure the deal's success, covering a wide range of issues on an internal business perspective. The time element in view of the lack of the ability to take a bold approach has many advantages such as allowing a wide range issues to be fully considered and constitutes the key to creating value. Taking the time to learn about its newly added structures and processes, CUG will engage in a self-reflective process of innovation and learning. This is a classic case of a deal that is not mainly about profit maximisation, but about exploration, survival and stasis. (Angwin, 2007) 
Figure 5 Balanced Scorecard Aspects of BFMAT Post-Merger

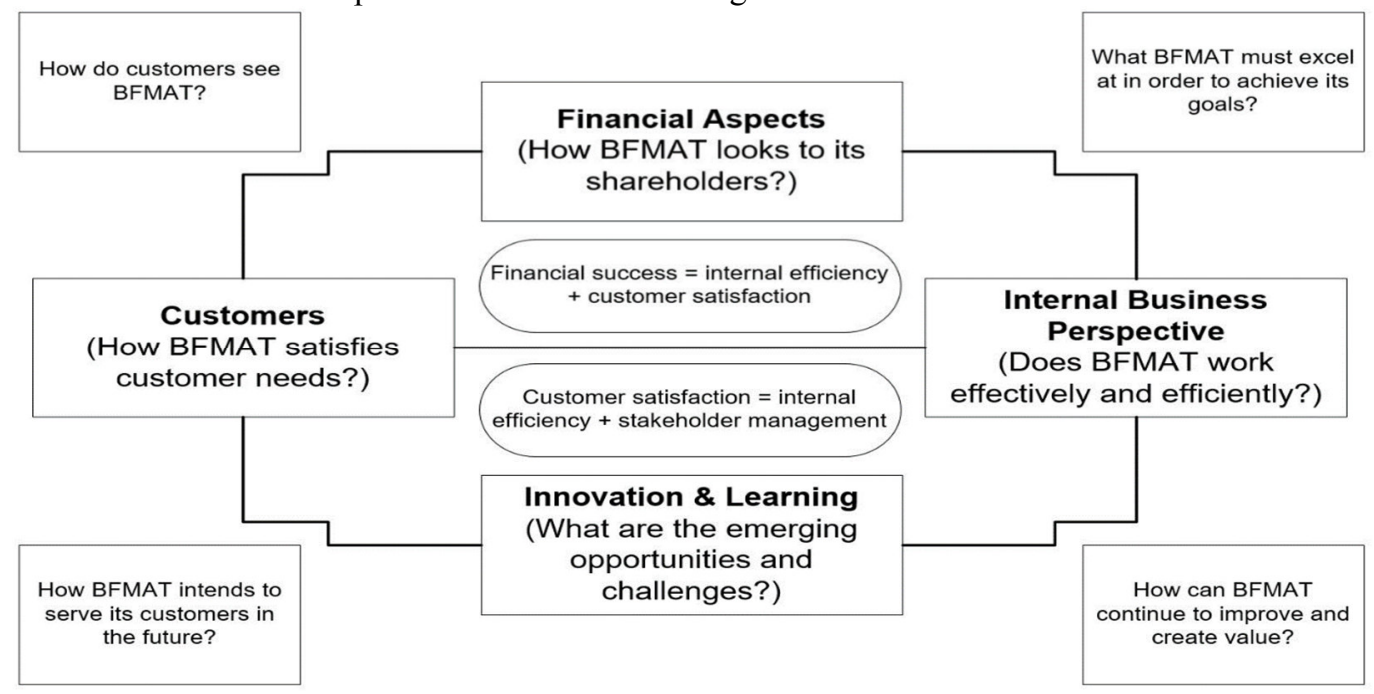

\subsection{Growth Strategies}

Based on its main quality KPIs (customer satisfaction, unified internal business processed and efficient stakeholder management), the CUG-BFMAT partnership seems to have found the answer to transformation and business stability. While overseas expansion has been high on CUG agenda for years, local merges help identify new markets nationally. This can be considered organic growth.

With recent coronavirus pandemic, online delivery has taken a new shape and what was planned to take place in the next five to ten years has suddenly seen light within four weeks in an unprecedented point of no return for the education business, which will certainly change the education landscape forever. It is forecasted that M\&A activities will expand to include new players such as educational institutions acquiring online delivery and various technology firms or vice versa. Geographical availability of educational institutions will soon be something of the past. (Papadakis \& Thanos, 2010) The only way to adapt to changing circumstances in education is adding the needed variety to the current business models to enhance business survival rate.

Figure 6 PESTLE Analysis

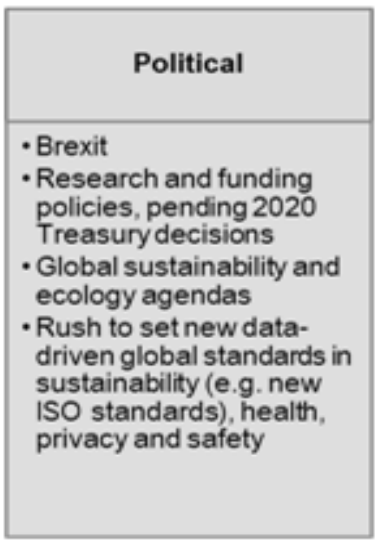

\section{Technological}

- Increasing online offer worlwide with significant competition in prices

- Numerous software teaching tools and online platforms available - Advent of Al for teaching
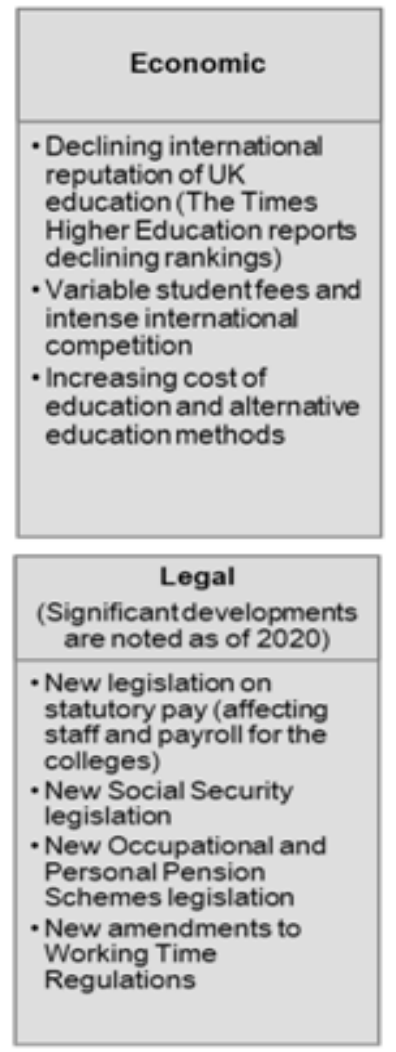

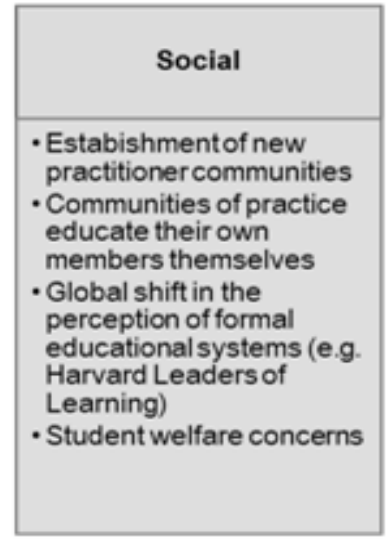

Environmental

\section{- The Alliance for}

Sustainability Leadership in Education (EAUC) has a growing network of colleges and universities

- SusTeach Planning tools (e.g. Open University) the educational scene 
The BFMAT merger with CUG occurs in an exciting global context broadly outlined in the PESTLE analysis in Figure 6 above. A number of the factors outlined are closely linked and affect one another. While post-Brexit education in the UK is expected to be mostly affected in terms of reduced EU funding and various economic factors that contribute to a decline in its reputation (The Times Higher Education trends) comparatively to other large education providers globally, there exist tendencies that will further affect colleges in the long run. These include new agendas and an internationally focused drive to set new standards in areas such as quality, sustainability, data security, safety, privacy, which in turn affect legal aspects of the work in the educational sector. Some of these standards will in the long-run affect colleges that will stand stronger when forming larger collectives that operate from locations closer to students or remotely via e-learning and distance learning opportunities. A good example of this is the EAUC and the drive to enhance "good business" in education through a sustainability agenda linked to institutions and bodies such as the Environment Agency but also to their global partners. In line with this the Open University develops a sustainable teaching tool intended to evaluate teaching and learning provision. These phenomena are linked to social factors that affect students and help democratise education. On the one hand, various social and economic factors will necessitate cheaper and more sustainable education options, resulting in less long-distance travel and online access. This is supported by technological advancement and social phenomena that permeate work environments with the formation of new communities of practice, new industry training centres and local communities taking education into their own hands as evidenced in the work of the Harvard Leaders of Learning community. The new legal aspects that find themselves in the most recent legal documents as of 2020 are partly the result of this new age in education and they reflect global trends that are progressively shifting popular perceptions of formal education and its advantages.

\section{Merger Impact on Coventry University Group}

Looking at Porter's Five Forces and their interaction for BFMAT and CUG, there are some clear trends that are reflects in the financial aspects that have been made publicly available.

\section{In terms of Supplier Power}

Supplier power if very high as BFMAT and CUG own complementary qualifications that ensure progression opportunities to their holders. They are able to decide on the range and scope of qualifications as well as the modes of delivery, including all strategic developments and prices for services are fixed and non-negotiable.

\section{Reflected in the Threat of New Entry}

The BFMAT merger with CUG counters the threat of its main competitor in the face of WMG Academy Trust operating in Coventry in partnership with WMG Group (Warwick University). The colleges within WMG Academy Trust are with similar "good" standing and have partnered with a competitor university. Essentially, the two institutions are rivals on the local market and mostly the exclusive magnets for local youth. Because of their size and spheres of influence, it is currently very difficult for any new entrants to constitute a threat to business.

\section{In terms of Buyer Power}

Buyer power is relatively limited as all BFMAT colleges are local and usually gather students from the environing areas. In its large majority, customer profile is A-level students between 16 and 19 years old, still living with family and looking for college (potentially university) opportunities closer to home.

\section{Reflected in the Threat of Substitution}

The only significant threat of substitution currently remains with online providers. However, due to the nature of the provision, this is highly unlikely to affect business in the short-run and within the next 5 years. However, in the long-run this my become more palpable. BFMAT and CUG are taking the right steps to develop distance and e-learning opportunities and to diversify their offer.

\subsection{Financial Analysis}

The three most widely used measures by Thanos and Papadakis (2012), managers' subjective assessments seem to be the most useful measure for CUG coupled with the other stakeholder objective and subjective assessments. Accounting-based measures and financial stability are also key in determining success, appropriate management and long-term stability. (Thanos \& Papadakis, 2012) However, in the case of CUG, measuring the merger impact becomes a complex issue as most educational institutions in the merger rely on political leadership directives and Government pre-set fees and grants which, in many cases, fail to reflect the fixed cost of the labour market and other costs.

From the financial analysis, it can be seen that CUG is more stable financially than BFMAT, which makes it difficult to determine the impact of the merges. Given the financial weight of BFMAT in comparison to CUG, it is unlikely that standard M\&A results reported in the literature will impact the university. Early evidence shows the merger creates value and efficiency. While efficiency realisation is low on the agenda given the soft approach taken, some evidence of resource deployment activities are seen, mainly at high level management integration. (Better Futures Multi-Academy Trust, 2019) Further integration activities are expected to take place, initially, 
perhaps, in the form of new qualifications to catch up with the fast-changing landscape. Impact on market will present another advantage of the trust that will include drawing clear lines between the FE and HE qualifications delivered by different parties. In recent years, the tension between $\mathrm{HE}$ and FE institutions has evolved to include competition at all levels across well-established qualifications, particularly Levels 3-6 with a series of new providers and awarding bodies, resulting in competitive rivalries between them. With the new apprenticeship standards, unfamiliar territory to all establishments, there is no doubt that such an integration will lead to creating the right formula to cope with the changes. The college benefits include clear defence tactics and create a sense of security being part of a bigger establishment. (Haleblian, et al., 2009) Table 2 Financial Analysis of Coventry University Group 2018-2019

\begin{tabular}{|c|c|c|c|c|c|c|}
\hline Coventry University Grp & 2014 & 2015 & 2016 & 2017 & 2018 & 2019 \\
\hline Total Income $(£ 000)$ & 241,720 & 271,399 & 305,117 & 330,402 & 368,726 & 402,042 \\
\hline \multirow[t]{2}{*}{ Total Expenditure $(£ 000)$} & 218,581 & 255,478 & 277,058 & 314,666 & 350,628 & 388,905 \\
\hline & 23,139 & 15,921 & 28,059 & 15,736 & 18,098 & 13,137 \\
\hline \multicolumn{4}{|l|}{ Academic Year } & $2017 / 2018$ & \multicolumn{2}{|l|}{ 2018/2019 } \\
\hline \multicolumn{4}{|l|}{ Income } & $368,726,000$ & \multicolumn{2}{|c|}{$402,042,000$} \\
\hline \multicolumn{4}{|l|}{ Expenditure } & $350,628,000$ & \multicolumn{2}{|r|}{$388,905,000$} \\
\hline \multicolumn{4}{|c|}{ Surplus before other gains and losses } & $18,098,000$ & \multicolumn{2}{|r|}{$13,137,000$} \\
\hline \multicolumn{4}{|c|}{ Gain on fixed assets and investments } & 148,000 & \multicolumn{2}{|r|}{$5,539,000$} \\
\hline \multicolumn{4}{|c|}{ Yearly surplus } & $16,597,000$ & \multicolumn{2}{|r|}{$19,549,000$} \\
\hline \multicolumn{4}{|c|}{ Student fee income (FT UK and EU) } & $164.5 \mathrm{~m}$ & \multicolumn{2}{|r|}{$174.8 \mathrm{~m}$} \\
\hline King Edward VI College & 2014 & 2015 & 2016 & 2017 & 2018 & 2019 \\
\hline Total Income $(£ 000)$ & 8,338 & 8,539 & 9,110 & 9,476 & 10,215 & 9,737 \\
\hline \multirow[t]{2}{*}{ Total Expenditure $(£ 000)$} & 8,322 & 8,563 & 9,001 & 9,874 & 9,724 & 9,887 \\
\hline & 16 & 24 & 109 & $(398)$ & $(490)$ & $(150)$ \\
\hline Bilborough College & 2014 & 2015 & 2016 & 2017 & 2018 & 2019 \\
\hline Total Income $(£ 000)$ & 8,846 & 9,035 & 8,847 & 8,658 & 7,667 & 10,010 \\
\hline \multirow[t]{2}{*}{ Total Expenditure $(£ 000)$} & 9,315 & 9,754 & 9,459 & 9,164 & 8,126 & 10,360 \\
\hline & $(469)$ & (719) & $(612)$ & $(506)$ & $(459)$ & $(350)$ \\
\hline $\begin{array}{lll}\text { Gateway } & \text { Sixth } & \text { Form } \\
\text { College } & & \end{array}$ & 2014 & 2015 & 2016 & 2017 & 2018 & 2019 \\
\hline Total Income $(£ 000)$ & $\mathrm{n} / \mathrm{a}$ & $\mathrm{n} / \mathrm{a}$ & $\mathrm{n} / \mathrm{a}$ & 8,263 & 8,579 & 7,103 \\
\hline \multirow[t]{2}{*}{ Total Expenditure $(£ 000)$} & $\mathrm{n} / \mathrm{a}$ & $\mathrm{n} / \mathrm{a}$ & $\mathrm{n} / \mathrm{a}$ & 9,031 & 8,555 & 7,912 \\
\hline & $\mathrm{n} / \mathrm{a}$ & $\mathrm{n} / \mathrm{a}$ & $\mathrm{n} / \mathrm{a}$ & (768) & 24 & (809) \\
\hline
\end{tabular}

This is based on publicly available released financial statements for the period 2014 to 2019 .

\subsection{Other Impacts}

The timing of this merge results from political and regulatory changes and shifting requirements. Law makers and politicians are under constant pressure to implement improvements in line with which renewed guidelines for educational quality have been released to providers. CUG strives to take advantage of key opportunities in education sector which many other institutions miss, specifically in the sphere of FE integration. The merge brings valuable college know-how and expertise to an HE institution.

Another reason for the success of this merger is the excellent level of knowledge the parties have of one another (Ahammada \& Glaister, 2013) and the timely communication of the impacts on relevant internal stakeholders. For CUG, evaluating current value and future business is relatively easy. Expanding college revenue is a low-urgency target. Local marketing and progression routes for current college students are priority. Common qualifications will have to be considered in the future. Overall, the experience so far seems to have had a higher positive impact on the colleges. For the average college employee, the merge reflects major changes in their work routine and culture. For university professors the impact will be minimal, and it is not expected to change in the foreseeable future.

Bauer and Matzler (2014) outline the non-standard nature of SMEs in their absence of market shares. (Bauer \& Matzler, 2014) This phenomenon is also valid for FE colleges where pre-merge analytical work can be difficult and inconclusive. Colleges hold poorly diversified portfolios (Gonenc, et al., 2013) and are in a sense much like family-owned firms as outlined by Gonenc et al. (2012). That is why, at a first glance it appears that CUG has utilised years of widely available M\&A literature to ensure the success of this transaction and has opted for a soft approach. The four dimensions of integration have been fully considered with a focus on marketing integration and planned system integration. Market integration is one of the main pillars of this merger, drawing clear parallels between qualification level and progression routes. Geographically targeted markets are a vital formula, ensuring 
sustainability. The sociocultural integration will remain a challenge but given the current degree and speed of integration it is evident that this has been thought of at both FE and HE leadership levels. Both ends of the management spectrum appear to appreciate the complex nature of the merge and adopt a soft approach to a graduated fusion of the activities of the trust with those of CUG.

Environmental uncertainty may not fully apply short-term but is a gradually developing trend and will gain in importance in the long run as evidenced by the PETSLE analysis. Sustainability drives good business and transposing corporate social responsibility concepts into the education business is profitable in the long run with CUG owning a charitable trust that drives an agenda of educational excellence. In terms of limitations and resource dependence, the merge results are not fully realised yet. Brexit and the local market scare of inability to hire qualified educators should be mitigated. There also is a clear evidence of underutilisation of physical resources that will have to be reviewed in the future.

\section{Recommendations}

Networking and collaboration are paramount factors in college merges. In the case of BFMAT, local authorities played a vital part in initiating and managing the merge while extensive stakeholder network is responsible for ensuring its continued success. To ensure success, some recommendations can be made (Papadakis, 2007) to maintain stability and achieve growth:

- Creating and celebrating early wins is easy to implement, given the constant yearly measures for FE and HE. This should be the regular focus on quality, inspection success, healthy financial results, and positive destinations.

- Cultural integration is attained by maintaining focus over time to ensure stability and achieve synergy. (Dyer, et al., 2004) Integration has started at executive level and will progressively extend to employees. Time factors should be considered here (Bauer \& Matzler, 2014) as a graduated approach that includes co-delivering qualifications.

- The new apprenticeship standards spanning Levels 2-7 are a good starting point. Higher qualifications and progression routes for college staff can be implemented, creating a positive atmosphere.

- Service areas (marketing, HR, quality) are easier to integrate given the nature of their common activities. Another stream of integration could include selected research and community projects and work with SMEs and schools. Many ex-European community development projects can be rebranded post-Brexit to readapt as collaboration endeavours between FE and HE partners and reap benefit from UK Government scheme substitutes.

- Preserving of both FE and HE cultures will require a low level of change for both the acquirer and the acquired.

- For years, FE colleges have been valued and promoted as life-changing for the lives of local people. It is important that the locality element of FE colleges remains unchanged while their outreach is widened and expanded to provide further national and international opportunities.

The rationale for this merge is ensuring success of vital processes, efficiency, financial stability, and consolidating market opportunities. Some aspects of not-for profit organisations ease the process and provides a strong platform for success, while others are challenging. Current political, environmental and global instability will constitute some of the challenges for BFMAT. However, the merge appears to have been realised for the right reasons with the right formula for success. The soft approach and the preservation of both cultures seem to be adapted with good reason. There is no doubt, however, that BFMAT will change and evolve within the next year as most educational institutions move into a new era of teaching and learning. The merge will provide it with relative strength and stability to face these changes which, inevitably, remain an essential part of our life in education henceforth.

The BFMAT case study reveals a potential for research into other mergers and acquisitions across higher education in the UK. The review of college mergers between 2019 and 2020 (Table 1) indicates that a number of merger and acquisition projects have taken place which remain to be investigated in the light of education business management. Their comparative study can reveal additional trends and impacts on the educational business as a whole, and may contribute to our understanding of the evolution of higher education in the $21^{\text {st }}$ century.

\section{References}

Ahammada, M. F. \& Glaister, K. W., 2013. The pre-acquisition evaluation of target firms and cross-border acquisition performance. International Business Review, Volume 22, pp. 894-904.

Angwin, D., 2007. Motive Archetypes in Mergers and Acquisitions (M\&A): The Implications of a Configurational Approach to Performance. Advances in Mergers and Acquisitions, Volume 6, pp. 77-105.

Association of Colleges, 2016. An Analysis of College Merger Issues, London: AoC.

Association of Colleges, 2016. Merger Tips, London: AoC.

Association of Colleges, 2020. Brexit and Colleges: AoC Position Paper, s.l.: AoC. 
Association of Colleges, 2020. College Mergers List, London: AoC.

Bauer, F. \& Matzler, K., 2014. Antecedents of M\&A Success: The Role of Strategic Complementrity, Cultural Fit, and Degree and Speed of Integration. Strategic Management Journal, 35(2), pp. 269-291.

Better Futures Multi-Academy Trust, 2019. Annual Report and Financial Statements, Coventry: BFMAT.

Bower, J. L., 2001. Not all M\&As are alike - and that matters. Harvard Business Review, March.

Burke, J., 2018. Bolton pilots new college-university merger model, s.1.: FE Week.

Burke, J., 2018. Ofsted: Bigger colleges aren't always better, s.l.: FE Week.

Department for Education, 2015. Prospects College of Advanced Technology project report: lessons learned and policy paper, London: Government UK.

Department for Education, 2019. Area Review: End of Programme Report: Restructuring of the FE Sector 20152019, 2019: Government UK.

Department of Business, Innovation and Skills, 2015. Current models of collaboration: post 14 further education, London: BIS.

Department of Business, Innovation and Skills, 2013. Competition Issues in the Further Education Sector, no. 141, London: BIS

Dyer, J., Kale, P. \& Singh, H., 2004. When to Ally \& When to Acquire. Top-Line Growth, July-August, pp. 108115.

Faulkner, D., Teerikangas, S. \& Joseph, R. J., 2012. The Handbook of Mergers and Acquisitions, s.1.: Oxford Scholarship Online.

Gomes, E., Angwin, D. N., Weber, Y. \& Tarba, S. Y., 2013. Critical Success Factors through the Mergers and Acquisitions Process: Revealing Pre- and Post-M\&A Connections for Improved Performance. Thunderbird International Business Review, 55(1).

Gonenc, H., Hermes, N. \& van Sinderen, E., 2013. Bidder's gains and family control of private target firms. International Business Review, Volume 22, pp. 856-867.

Haleblian, J. et al., 2009. Taking Stock of What We Know About Mergers and Acquisitions: A Review and Research Agenda. Journal of Management, 35(3), pp. 469-502.

Jack, A., 2019. Further education colleges struggle to cope with UK funding squeeze. Financial Times, 26 June.

Johnson, C., 2017. Mergers in the further education sector. Charity and Social Enterprise Update: Education Focus.

Johnson, G. et al., 2017. Exploring Strategy. ProQuest Ebook ed. Harlow, United KIngdom: Pearson Education Limited.

Martynova, M. \& Renneboog, L., 2008. A century of corporate takeovers: What we have learned and where do we stand?. Journal of Banking \& Finance, Volume 32, pp. 2148-2177.

Papadakis, V., 2007. Growth through mergers and acquisitions: how it won't be a loser's game. Business Strategy Series, 8(1), pp. 43-50.

Papadakis, V. M. \& Thanos, I. C., 2010. Measuring the Performance of Acquisitions: An Empirical Investigation Using Multiple Criteria. British Journal of Management, Volume 21, pp. 859-873.

Popov, D. \& Cattoretti, G., 2019. The Impact of College Mergers in Further Education, London: Department for Education.

Thanos, I. C. \& Papadakis, V. M., 2012. The Use of Accounting-based Measures in Measuring M\&A Performance: A Review of Five Decades of Research. Advanced in Mergers and Acquisitions, Volume 10, pp. 103-120. 